\title{
AlEXANDER VON HUMBOLDT FOUNDATION
}

\begin{tabular}{|c|}
\hline $\begin{array}{c}\text { INFOR M TION STIETT } 1994 \\
\text { Transatlantic Research Cooperation } \\
\text { Bunyan German and American Scholars in the Humanities } \\
\text { and Social Sciences } \\
\text { (Transcoop Program) }\end{array}$ \\
\hline Deadline: December 15, 1993 \\
\hline $\begin{array}{l}\text { Program Description } \\
\text { The Alexander von Humboldt Foundation has acquired additional funds to finance } \\
\text { long term joint research projects between American and German scholars in all fields } \\
\text { of the humanities and social sciences, including law and economics. The maximum } \\
\text { duration of sponsorship for a Transcoop project is three years. In } 1994 \text { approximately } \\
\$ 400,000 \text { from German sources will be available. The Transcoop program offers } \\
\text { opportunities to researchers from both universities and non-university research } \\
\text { institutions in both countries. Ideally, joint projects in the humanities and social } \\
\text { sciences will relate to problems of the natural sciences, including the engineering and } \\
\text { life sciences. However, all other topics are also eligible for joint research projects. } \\
\text { Long-term Transcoop projects make funds available for: } \\
\text { - short-term research visits (up to onemonth per year for each partner, German and } \\
\text { American) - travel costs - special conferences closely related to the research } \\
\text { project - additional expenses for materials and equipment - printing costs for } \\
\text { publications-payment of research assistance, e.g., data adhering (maximum } 10 \% \\
\text { of the total). }\end{array}$ \\
\hline
\end{tabular}

It is assumed that home institutions will continue paying the salaries of scholars and their assistants. Overhead costs can be included up to $20 \%$. Transcoop projects can be supported by funds from the German side up to $\$ 50,000$. Every project must be matched by funds from a U.S. source which the U.S. partner should identify in the application. If the U.S. contribution is less than $\$ 50,000$, the German contribution will be limited to that smaller amount.

\section{Grant Procedure}

Applications should be submitted jointly by at least one U.S. and one German scholar directly to the Humboldt Foundation in Bonn. Each applicant should at least hold a Ph.D. The Selection Committee of the Humboldt Foundation will base its decision on the following criteria:

- the project's potential for strengthening transatlantic cooperation

- the academic qualifications of applicants

- the originality of the research project.

Decisions are based solely on scholarly merit as documented in the application. Selection of candidates is made by a peer-review committee of the Humboldt Foundation

The Dupont Circle Building • 1350 Connecticut AV., N.W., Suite 903 - Washington, DC 20036

Phone: (202) 296-2990 - Fax: (202) 833-8514 - E-Mail: humboldt@umail.umd edu

Main Office: Jean-Paul-Str. 12 • 53173 Bonn • Germany • Phone: 49 (228) 833-0 • Fax: 49 (228) 833-199 
Robert F. Byrnes

Kliuchevskii's View of Russian History

Milton Fisk

Community and Morality

Ronald Beiner

Machiavelli, Hobbes, and Rousseau on Civil Religion

Mark Bevir

Welfarism, Socialism and Religion

Hans-Georg Betz

The Two Faces of Radical Right-Wing

Populism in Western Europe

Louis Dupré

The Common Good and the Open Society

Book Reviews featuring E. A. Goerner on John Rawls's Political Liberalism and Harrison J. Sheppard on George Anastaplo's American Moralist 